\title{
Multivariate analysis in the morpho-yield evaluation of forage cactus intercropped with sorghum
}

\author{
Alexandre M. da R. F. Jardim¹, Thieres G. F. da Silva², Luciana S. B. de Souza², Marcondes de S. Souza ${ }^{3}$, \\ José E. F. de Morais $^{1} \&$ George do N. Araújo Júnior ${ }^{1}$ \\ ${ }^{1}$ Universidade Federal Rural de Pernambuco/Departamento de Engenharia Agrícola/Programa de Pós-Graduação em Engenharia Agrícola. Recife, PE, \\ Brasil. E-mail: alexandremrf@gmail.com (Corresponding author) - ORCID: 0000-0001-7094-3635; joseedson50@hotmail.com - ORCID: 0000-0002- \\ 3641-2221; georgearaujo.agro@gmail.com - ORCID: 0000-0001-9284-4160 \\ ${ }^{2}$ Universidade Federal Rural de Pernambuco/Unidade Acadêmica de Serra Talhada/Programa de Pós-Graduação em Produção Vegetal. Serra Talhada, \\ PE, Brasil. E-mail: thieres.silva@ufrpe.br - ORCID: 0000-0002-8355-4935; sanddrabastos@yahoo.com.br - ORCID: 0000-0001-8870-0295 \\ ${ }^{3}$ Universidade Federal Rural de Pernambuco/Departamento de Agronomia/Programa de Pós-Graduação em Ciência do Solo. Recife, PE, Brasil. E-mail: \\ marcondes.sa33@gmail.com - ORCID: 0000-0003-4944-4887
}

\begin{abstract}
Understanding the effect of the cropping system on the morpho-yield relationship of plants is crucial for success in the agricultural activity, mainly in arid and semi-arid regions, where there are major challenges for food production. In this study, the objective was to apply multivariate statistics in the morpho-yield evaluation of forage cactus clones in cropping systems as sole crop and intercropped with sorghum cultivars. The experiment was conducted in Serra Talhada, PE, Brazil, between March 18, 2017 and June 16, 2018. The design adopted was in randomized blocks with 12 treatments composed of three forage cactus clones in sole-crop system (IPA Sertânia, Miúda and Orelha de Elefante Mexicana) and nine forage cactus-sorghum intercropping systems with the cultivars 467, SF11 and 2502. Morphometric and phytomass measurements of forage cactus clones were performed throughout the cycle. The relationship between the morpho-yield traits of the clones was evaluated by means of principal component analysis. Cladode width, length, perimeter, and area are morphometric variables that determine phytomass accumulation in clones. The cropping systems did not influence the association of morpho-yield traits, but it depends on the genus of forage cactus. Negative correlations between cladode dimensions and phytomass of the clones of the genus Nopalea explained their lower phytomass accumulations. Principal components analysis makes it possible to elucidate associations between morpho-yield variables of forage cactus.
\end{abstract}

Key words: Opuntia, Nopalea, Sorghum spp., principal component analysis

\section{Análise multivariada na avaliação morfo-produtiva da palma forrageira consorciada com o sorgo}

RESUMO: O entendimento do efeito do sistema de cultivo sobre a relação morfo-produtiva das plantas é determinante para o sucesso da atividade agrícola, sobretudo em regiões áridas e semiáridas, onde há grandes desafios para produção de alimentos. Neste estudo, objetivou-se aplicar estatística multivariada na avaliação morfo-produtiva de clones de palma forrageira em sistemas de cultivo exclusivo e consórcio com cultivares de sorgo. O experimento foi conduzido em Serra Talhada, PE, entre 18 de março de 2017 e 16 de junho de 2018. O delineamento adotado foi em blocos casualizados com 12 tratamentos compostos por três clones de palma em sistema exclusivo (IPA Sertânia, Miúda e Orelha de Elefante Mexicana) e nove consórcios palma-sorgo com as cultivares 467, SF11 e 2502. Medidas morfométricas e de fitomassa dos clones de palma foram feitas ao longo do ciclo. Avaliou-se a relação entre as características morfo-produtivas dos clones por análise de componentes principais. A largura, comprimento, perímetro e área do cladódio são as variáveis morfométricas que determinam o acúmulo de fitomassa em clones de palma. Os sistemas de cultivo não afetaram a associação de características morfo-produtivas, mas esta depende do gênero de palma. Correlações negativas entre as dimensões dos cladódios e a fitomassa dos clones do gênero Nopalea explicaram os seus menores acúmulos de fitomassa. Verificou-se que a análise de componentes principais permite elucidar as associações entre variáveis morfo-produtivas da palma.

Palavras-chave: Opuntia, Nopalea, Sorghum spp., análise de componentes principais 


\section{INTRODUCTION}

The growing demand for food has greatly increased the challenges for production in sustainable agroecosystems, especially in arid and semi-arid regions, where crops are even more affected by stressors arising from environmental conditions and/or from cropping (Ginkel et al., 2013; Bjørge et al., 2018).

Using species that are adapted to environments with water deficit is an alternative in the agricultural sectors. For the livestock farming of the Brazilian semi-arid region, forage cactus (Opuntia spp. and Nopalea spp.) plays an important role as a food source for herds due to its rusticity and low water requirement (Silva et al., 2015; Morais et al., 2017; Hassan et al., 2019). In addition, sorghum (Sorghum spp.) has high forage production and suitability to different cropping configurations, including intercropping with forage cactus (Diniz et al., 2017; Lima et al., 2018).

Understanding the effect of the cropping system on the morpho-yield relationship of plants is determinant for the success of agricultural activity (Neder et al., 2013). For this, multivariate statistical analyses (i.e. principal component analysis) can be applied, since they make it possible to group the data in a covariance matrix and identify more associated variables, thus reducing the set of information (Barbosa et al., 2017a; Steidle Neto et al., 2018).

Some studies have been carried out to analyze the association of morphometric traits with the yield of forage cactus clones in sole-crop, rainfed or irrigated cultivation (Neder et al., 2013; Barbosa et al., 2017b; 2018a), but none with intercropping. This study aimed to apply multivariate statistics in the morpho-yield evaluation of forage cactus in sole-crop cultivation and intercropped with sorghum cultivars.

\section{Material ANd Methods}

The experiment was conducted at the Academic Unit of Serra Talhada, Federal Rural University of Pernambuco, located in the municipality of Serra Talhada, PE, Brazil (geographic coordinates: 7056'20" S; 38 $38^{\circ} 11^{\prime \prime}$ ' W, and altitude of $499 \mathrm{~m}$ ). The climate of the region is BSwh', semi-arid (Alvares et al., 2013), with predominance of rainfall in the warmer months and dry season occurring in the cold months of the year.

The soil of the experimental area is Inceptisol with flat relief and showing the physico-chemical attributes in the $0-0.20 \mathrm{~m}$ layer presented in Table 1.

Three clones of forage cactus (Orelha de Elefante Mexicana - OEM, Opuntia stricta (Haw.) Haw.; IPA Sertânia - IPA, Nopalea cochenillifera (L.) Salm-Dyck; and Miúda - Miu,
Nopalea cochenillifera (L.) Salm-Dyck) were planted between February 1 and 15, 2016, after the initial soil tillage with plowing, harrowing and furrowing. The cladodes of the clones were planted vertically in the soil and spaced at $1.0 \times 0.2 \mathrm{~m}$, which resulted in equivalent density of 50,000 plants ha ${ }^{-1}$.

Between planting and January 31, 2017, the clones were grown under rainfed conditions. From this date, a drip irrigation system was installed. On March 17, 2017, a uniformity cut was performed, keeping the basal and first-order cladodes. The experimental period began on March 18, 2017, and lasted until June 16, 2018 (15 months), during which the forage cactus clones were intercropped with three sorghum (Sorghum spp.) cultivars.

The cultivars 467, SF11 and 2502 were sown on March 18, 2017 , in continuous rows spaced apart by $1.0 \mathrm{~m}$ and at $0.25 \mathrm{~m}$ distance from the forage cactus row. Twenty-eight days after emergence, the seedlings were thinned, maintaining 20 plants per linear meter (equivalent density of 200,000 plants ha ${ }^{-1}$ ). The cultivars were grown for four cycles (one plant cycle and three regrowth cycles: $1^{\text {st }}, 2^{\text {nd }}$ and $3^{\text {rd }}$ ) within the 15 months of forage cactus cycle.

Two mineral fertilizations were performed using NPK fertilizer with the 14-00-18 + 16 S formulation, which corresponded to $73.5 \mathrm{~kg} \mathrm{~N} \mathrm{ha}^{-1}, 94.5 \mathrm{~kg} \mathrm{~K}_{2} \mathrm{O} \mathrm{ha}^{-1}$ and $84 \mathrm{~kg} \mathrm{Sha}^{-1}$, the first one as basal and the other as top-dressing, according to Diniz et al. (2017) and Lima et al. (2018).

The experiment was conducted in randomized blocks with 12 treatments, consisting of the three forage cactus clones in sole-crop system (OEM Sole, IPA Sole and Miu Sole) and nine forage cactus-sorghum intercropping systems from the combinations of the clones with the sorghum cultivars: $\mathrm{OEM}+467, \mathrm{OEM}+\mathrm{SF} 11, \mathrm{OEM}+2502, \mathrm{IPA}+467, \mathrm{IPA}+\mathrm{SF} 11$, $\mathrm{IPA}+2502, \mathrm{Miu}+467, \mathrm{Miu}+\mathrm{SF} 11$ and Miu+2502, with four replicates. The experimental unit comprised four rows and 100 forage cactus plants, totaling an area of $60 \mathrm{~m}^{2}$. The usable plot was formed by the central rows, with 46 usable plants, resulting in a usable area of $16.4 \mathrm{~m}^{2}$.

Irrigations were performed based on the evapotranspiration of the forage cactus crop (main crop) obtained from the product of crop coefficient with reference evapotranspiration (ETo). ETo was calculated using the Penman-Monteith method standardized by FAO Bulletin 56 (Allen et al., 1998), and the meteorological data were collected from an automatic station of the National Institute of Meteorology (http://www.inmet.gov.br) located 20 $\mathrm{m}$ away from the experimental area. A crop coefficient of 0.52 was adopted for the entire cycle, as proposed by Queiroz et al. (2016) and ratified by Lima et al. (2018).

The drip irrigation system was composed of drip tapes $\left(1.75 \mathrm{~L} \mathrm{~h}^{-1} ; 100 \mathrm{kPa}\right)$, with drippers spaced apart by $0.20 \mathrm{~m}$. The

Table 1. Physico-chemical attributes of the soil of the experimental area in the $0-0.20 \mathrm{~m}$ layer

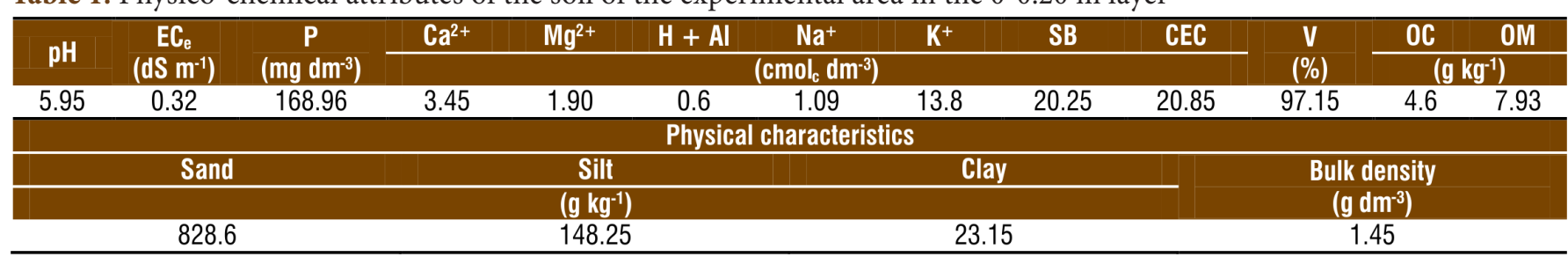

pH in $\mathrm{H}_{2} \mathrm{O}$ at 1:2.5 ratio, v/v; EC - Electrical conductivity of the soil saturation extract; P - Extracted with Mehlich-1 solution; SB - Sum of bases; CEC - Cation exchange capacity; $\mathrm{V}$ - Base saturation; OC - Organic carbon; OM - Organic matter; Analyses according to the methodology of EMBRAPA (2017) 
water used in the irrigations showed electrical conductivity of $1.51 \mathrm{dS} \mathrm{m}^{-1}$, being classified as of high salinity (C3) (Richards, 1954); $\mathrm{pH}=6.84 ; \mathrm{Na}^{+}=168.66 \mathrm{mg} \mathrm{L}^{-1}$ and $\mathrm{K}^{+}=28.17 \mathrm{mg} \mathrm{L}^{-1}$.

Rainfall events were concentrated between February and July 2017 and from February to May 2018, accumulating $997 \mathrm{~mm}$ during the 15-month experimental period (Figure 1). The water depth applied via irrigation totaled $623 \mathrm{~mm}\left(1.4 \mathrm{~mm} \mathrm{~d}^{-1}\right)$. The average ETo was $4.7 \mathrm{~mm} \mathrm{~d}^{-1}$, with a maximum of $7.5 \mathrm{~mm} \mathrm{~d}^{-1}$ and minimum of $0.4 \mathrm{~mm} \mathrm{~d}^{-1}$, with accumulation of $2,431 \mathrm{~mm}$. The seasonality of rainfall and ETo events plus the regularity of irrigation application are in accordance with the requirements of the forage cactus-sorghum intercropping cited by Diniz et al. (2017) and Lima et al. (2018).

Every three months, morphometric and phytomass evaluations were carried out in the forage cactus clones, resulting in five samplings, when the crop was at 126, 280, 317,413 , and 455 days after cutting (samples 1, 2, 3, 4 and 5, respectively). At the moments of samplings 1, 2, 3 and 4 in forage cactus plants, the sorghum cultivars were in the cycles of plant (age: 114 days), second regrowth (age: 56 days), third regrowth (age: 20 days) and third regrowth (age: 116 days), respectively. At the time of the fifth sampling, the sorghum cultivars had already been harvested.

Morphometric measurements were performed in two plants per plot using a tape measure and a caliper, according to methods suggested by Silva et al. (2014a). The following parameters were recorded: plant height $(\mathrm{PH})$ (distance from the soil surface to the upper end of the highest cladode) and plant width (PW) (horizontal dimension between the most extreme cladodes of the plant); cladode length (CL) and cladode width $(\mathrm{CW})$ (vertical and horizontal dimensions of the cladode); cladode perimeter (CP); cladode thickness (CT) (measured in the middle third); and total number of cladodes per plant (TNC).

From the data of CL, CW and CP, cladode area $\left(\mathrm{CA}, \mathrm{cm}^{2}\right)$ was calculated according to Silva et al. (2014a). The data of CA was used to calculate the cladode area index (CAI, $\mathrm{m}^{2} \mathrm{~m}^{-2}$ ) adopting the non-destructive method described by Pinheiro et al. (2015), according to Eq. 1.

$$
\mathrm{CAI}=\left[\frac{\sum_{\mathrm{n}}^{\mathrm{i}=1}(\mathrm{CA})}{\frac{10000}{(\mathrm{~S} 1 \cdot \mathrm{S} 2)}}\right]
$$

where:

CAI - observed cladode area index, $\mathrm{m}^{2} \mathrm{~m}^{-2}$;

CA - cladode area, $\mathrm{cm}^{2}$;

10,000 - correction factors from $\mathrm{cm}^{2}$ to $\mathrm{m}^{2}$;

$\mathrm{n}$ - number of observations; and,

S1 x S2 - corresponds to the spacing between rows and between plants $(1.0 \times 0.2 \mathrm{~m})$.

The phytomass variables of the forage cactus clones obtained were: total fresh mass (FM, $\left.\mathrm{Mg} \mathrm{ha}^{-1}\right)$, total dry mass (DM, $\mathrm{Mg} \mathrm{ha}^{-1}$ ) and dry mass content (DMC, $\mathrm{Mg} \mathrm{Mg}^{-1}$ ), the latter being obtained by the ratio between DM and FM. For this, one plant per plot (one of the two plants used in the morphometric measurement stage), on the different sampling dates, was sampled, keeping the basal and first-order cladodes. The plants were weighed (fresh mass) on a precision scale and then fragmented, placed in paper bags and dried in a forced air ventilation oven at $55^{\circ} \mathrm{C}$, until reaching constant dry weight within five to seven days (Silva et al., 2014b).

Morphometric and fresh mass (FM), dry mass (DM) and dry mass content (DMC) data of forage cactus clones in the different cropping systems (sole crop and intercropped with sorghum) were subjected to principal component analysis - (PCA) to identify the effects of cropping systems, clone and/or genus on the association of morpho-yield variables of forage cactus. The original data were decomposed into sets of orthogonal vectors. The results of the correlation matrix were displayed in biplots with their distribution in the space of ordering, variances and Pearson's correlation $(\alpha=0.05)$. Statistical analyses were carried out in the software program R 4.0.1 (R Core Team, 2020).

\section{RESULTS AND Discussion}

Figure 2 shows the results of the principal component analyses (PCAs) between the morphometric and phytomass

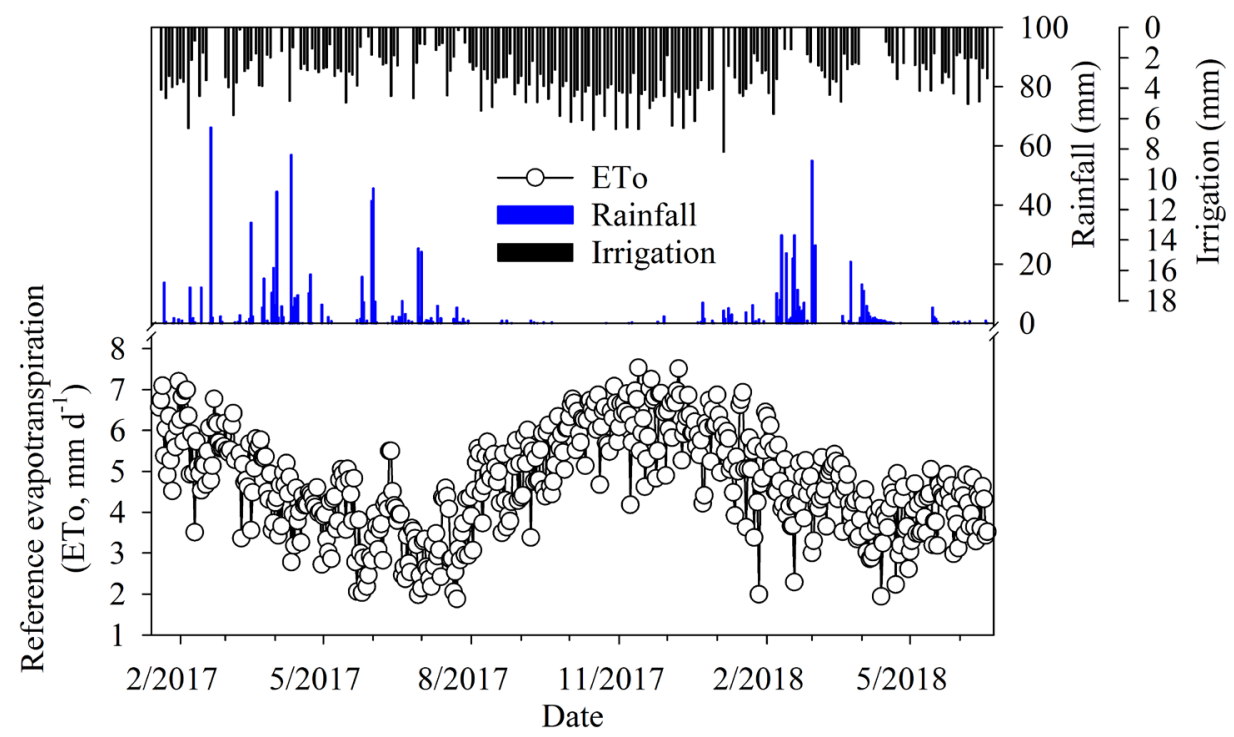

Figure 1. Rainfall, reference evapotranspiration and irrigation from March 18, 2017 to July 16, 2018 
A.

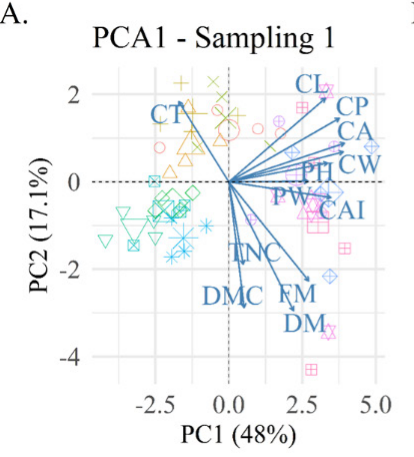

D.

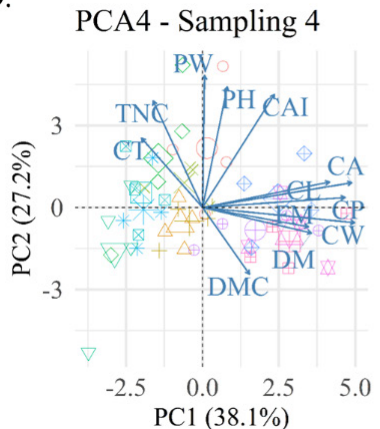

B.

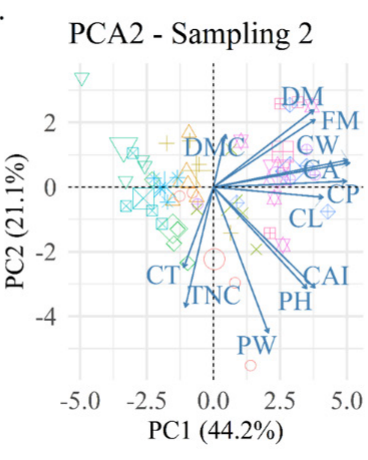

E.

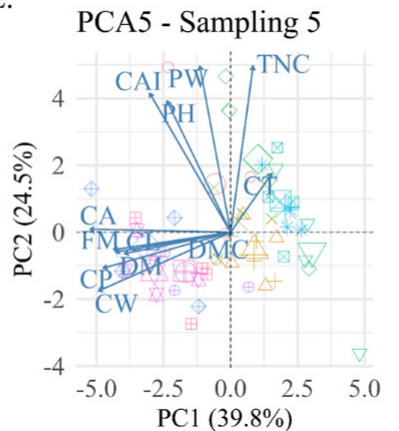

C.

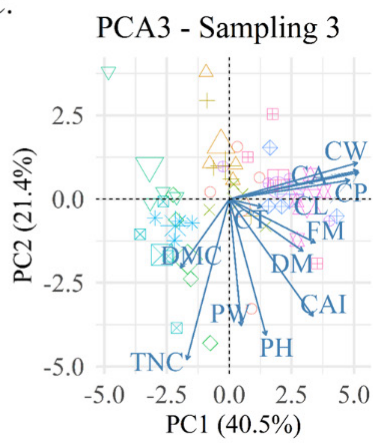

Treatments IPA Sole IPA +2502 IPA+467 IPA+SF11 Miu Sole $\mathrm{Miu}+2502$ Miu+467 $\mathrm{Miu}+\mathrm{SF} 11$ OEM Sole OEM+2502 $\mathrm{OEM}+467$ OEM+SF 11

OEM - Orelha de Elefante Mexicana; IPA - IPA Sertânia; Miu - Miúda; Sole - Sole cropping; PH - Plant height; PW - Plant width; TNC - Total number of cladodes; CL - Cladode length; CW - Cladode width; CT - Cladode thickness; CP - Cladode perimeter; CA - Cladode area; CAI - Cladode area index; FM - Fresh mass; DM - Dry mass; DMC - Dry mass content Figure 2. Principal component analyses between morphometric and phytomass variables of forage cactus clones under sole crop system and intercropping with sorghum cultivars (467, SF11 and 2502) at 126, 280, 317, 413, and 455 days after cutting (Samplings 1, 2, 3, 4 and 5 refer to Figures 2A, B, C, D and E, respectively)

variables in five cycles of forage cactus cultivated as sole crop or intercropped with three sorghum cultivars. In general, the PCAs explained above $60 \%$ of the data variation and made it possible to identify the association of morpho-yield variables, being more dependent on the genus than on the cropping arrangements of the forage cactus-sorghum intercropping, since Figure 2 showed no formation of different groups between the configurations of sole crops and intercropping with the sorghum cultivars.

The effect of forage cactus-sorghum intercropping on morphometric traits, production of cladodes and/or phytomass accumulation by forage cactus has been reported by Amorim et al. (2017), Diniz et al. (2017) and Lima et al. (2018), but was not seen in this study. Forage cactus growth dynamics depends on multiple factors (i.e. clones, cutting management, environmental conditions, phenotypic plasticity etc.), so their effects may not be detected with the application of PCA (Morais et al., 2017; Barbosa et al., 2018a; b).

In Sampling 1 (forage cactus at 126 days after cutting; Figure 2A), the principal components 1 (PC1) and 2 (PC2) explained, respectively, 48 and $17.1 \%$ of the association between morphometric and phytomass variables. In PC1, plant height $(\mathrm{PH})$, plant width (PW), cladode area index (CAI) and cladode dimensions (Length - CL, Width - CW, Perimeter $\mathrm{CP}$, Area - CA) were highly associated with one another and with fresh mass (FM), in particular, for Orelha de Elefante Mexicana, regardless of the cropping system. On the other hand, PC2 revealed the positive correlation of dry mass content (DMC) and dry mass (DM) with the total number of cladodes (TNC) and cladode thickness (CT), but the latter with negative correlation. For forage cactus, high and positive correlations between morpho-yield traits help in the choice of accessions for breeding programs (Neder et al., 2013).
In Sampling 2 (forage cactus at 280 days after cutting; Figure 2B), PC1 explained $44.2 \%$ of data variability and, summed with PC2, explained $65.3 \%$ of the total variance. The variables $\mathrm{CW}$, $\mathrm{CL}$ and $\mathrm{CP}$ exhibited a high correlation with $\mathrm{CA}$, and this with CAI, FM and DM. Silva et al. (2014a) state that the dynamics of CW, CL and CP determines cladode area, which assists in photosynthetic capacity and carbon assimilation by the crop. Barbosa et al. (2018a) mention that cladode dimensions are fundamental in defining the growth of forage cactus canopy, but depend more on peculiarities of the genera than on the traits of the clones.

Negative correlations between cladode dimensions and phytomass of IPA Sertânia and Miúda explain the lower phytomass accumulation of these clones, despite the greater number of cladodes in Miúda. Theoretically, the greater presence of cladodes in the plant helps in light interception and contributes to the production of sugars (Nobel \& Zutta, 2008), but for Miúda this statement may not be confirmed because of the small area of its cladodes (Silva et al., 2014a; 2015).

At 317 days after cutting (Sampling 3), PC1 and PC2 explained 40.5 and $21.4 \%$ of the data variation, respectively (Figure 2C). The association of the morphometric traits $\mathrm{CW}, \mathrm{CL}, \mathrm{CP}, \mathrm{CA}$ and CAI with the variables FM and DM were similar to those found in Sampling 2, while the highest TNC and DMC were more related to the clone Miúda. From 413 days after cutting (Sampling 4) and at the time of harvest, at 455 days after cutting (Sampling 5), the phytomass accumulation by forage cactus was further explained by cladode dimensions (CW, CL, CP and CA) than potentially associated with TNC and CAI. Pinheiro et al. (2015) found that TNC, CAI and the morphology of the fourth-order cladodes are the variables that best explain forage cactus 
yield, but in rainfed crops. Under irrigation, Barbosa et al. (2017b) mention that, regardless of the water regime and the clone, the vigor of the basal cladode seems to be decisive in the production capacity of forage cactus.

The change in the importance of some morphogenic traits in explaining phytomass accumulation by forage cactus can be justified by the influence of environmental variables on its growth dynamics. After the first rainfall events, the forage cactus growth rate increases significantly, but tends to be more persistent when it is subjected to regular irrigation depths (Pereira et al., 2015). For Barbosa et al. (2018a), forage cactus clones have a differentiated environmental requirement that depends on the type of genus; higher intensities of global solar radiation affect clones of the genus Nopalea more than those of the genus Opuntia, while Opuntia clones have a lower response to temperature.

Changes in weather conditions and morphological traits of clones throughout the cycle affect the water consumption of forage cactus and, consequently, its phytomass accumulation (Barbosa et al., 2017a; Morais et al., 2017). However, the high capacity to store water in the cladodes prolongs the growing period of the crop under water restriction conditions (Silva et al., 2015; Barbosa et al., 2017b), thus confirming its high water use efficiency (Silva et al., 2014b; Morais et al., 2017; Lima et al., 2018).

In the present study, Nopalea clones exhibited morphometric traits that explain the lower production capacity when compared to O. stricta, the clone Orelha de Elefante Mexicana. The relationship of morphometric traits with the phytomass of clones within the Nopalea and Opuntia genera corroborates the results of Rocha et al. (2020), who used hierarchical cluster analysis to evaluate the convergence between plant height and dry mass production.

The results of this study also show the usefulness of PCA in elucidating differences between the traits of clones of different forage cactus genera, although there was no effect of the cropping arrangements. PCA has already been applied in various studies with forage cactus (García-Nava et al., 2015; Mottese et al., 2018), which suggests the potential of this tool in the most different areas of knowledge. For example, as it is not always possible to perform plant samplings to measure fresh and dry mass, the use of multivariate analyses is very useful to evaluate the production capacity of cactus species (Neder et al., 2013; Reis et al., 2018).

\section{Conclusions}

1. Cladode width, length, perimeter and area are morphometric variables that determine phytomass accumulation in forage cactus clones.

2. The association of morphometric variables with the phytomass variables of forage cactus varied according to its genus, with no influence of cropping systems.

3. Negative correlations between cladode dimensions and phytomass of clones of the genus Nopalea (IPA Sertânia and Miúda) explained their lower phytomass accumulations when compared to the clone of the genus Opuntia, Orelha de Elefante Mexicana.
4. Principal component analysis makes it possible to elucidate associations between morpho-yield variables of forage cactus.

\section{ACKNowledgments}

The authors thank the Coordination for the Improvement of Higher Education Personnel (CAPES - Financial Code 001) for the scholarships, the Fundação de Amparo à Ciência e Tecnologia do Estado de Pernambuco. (FACEPE - APQ-02155.01/10 and FACEPE - APQ-1159-1.07/14) and the Conselho Nacional de Desenvolvimento Científico e Tecnológico (CNPq - 475279/2010-7, 476372/2012-7, 305286/2015-3 and $309421 / 2018-7)$ for the financial support.

\section{Literature Cited}

Allen, R. G.; Pereira, L. S.; Raes, D.; Smith, M. Crop evapotranspiration: Guidelines for computing crop water requirements. Rome: FAO, 1998. 301p. Irrigation and Dranaige, Paper 56

Alvares, C. A.; Stape, J. L.; Sentelhas, P. C.; Gonçalves, J. L. M.; Sparovek, G. Köppen's climate classification map for Brazil. Meteorologische Zeitschrift, v.22, p.711-728, 2013. https://doi. org/10.1127/0941-2948/2013/0507

Amorim, D. M.; Silva, T. G. F. da; Pereira, P. de C.; Souza, L. S. B. de; Minuzzi, R. B. Phenophases and cutting time of forage cactus under irrigation and cropping systems. Pesquisa Agropecuária Tropical, v.47, p.62-71, 2017. https://doi.org/10.1590/1983-40632016v4742746

Barbosa, M. L.; Silva, T. G. F. da; Zolnier, S.; Silva, S. M. S e; Araújo Junior, G. do N.; Jardim, A. M. da R. F. Meteorological variables and morphological characteristics influencing the evapotranspiration of forage cactus. Revista Ceres, v.64, p.465-475, 2017a. https://doi.org/10.1590/0034-737x201764050003

Barbosa, M. L.; Silva, T. G. F. da; Zolnier, S.; Silva, S. M. S. e; Ferreira, W. P. M. Environmental variables influencing the expression of morphological characteristics in clones of the forage cactus. Revista Ciência Agronômica, v.49, p.399-408, 2018a. https://doi. org/10.5935/1806-6690.20180045

Barbosa, M. L.; Silva, T. G. F. da; Zolnier, S.; Silva, S. M. S. e; Morais, J. E. F. de; Assis, M. C. de S. Association of morphological and water factors with irrigated forage cactus yield. Revista Brasileira de Engenharia Agrícola e Ambiental, v.21, p.600-605, 2017b. https:// doi.org/10.1590/1807-1929/agriambi.v21n9p600-605

Barbosa, M. L.; Silva, T. G. F. da; Zolnier, S.; Silva, S. M. S. e; Steidle Neto, A. J. The influence of cladode morphology on the canopy formation of forage cactus plants. Revista Caatinga, v.31, p.180190, 2018b. https://doi.org/10.1590/1983-21252018v31n121rc

Bjørge, J. D.; Overgaard, J.; Malte, H.; Gianotten, N.; Heckmann, L. H. Role of temperature on growth and metabolic rate in the tenebrionid beetles Alphitobius diaperinus and Tenebrio molitor. Journal of Insect Physiology, v.107, p.89-96, 2018. https:/doi. org/10.1016/J.JINSPHYS.2018.02.010

Diniz, W. J. da S.; Silva, T. G. F. da; Ferreira, J. M. da S.; Santos, D. dos C.; Moura, M. S. B. de; Araújo, G. G. L. de; Zolnier, S. Forage cactus-sorghum intercropping at different irrigation water depths in the Brazilian Semiarid Region. Pesquisa Agropecuária Brasileira, v.52, p.724-733, 2017. https://doi.org/10.1590/S0100204X2017000900004 
EMBRAPA - Empresa Brasileira de Pesquisa Agropecuária. Manual de métodos de análise de solo. 3.ed. Brasília: Embrapa Informação Tecnológica, 2017. 573p.

García-Nava, F.; Peña-Valdivia, C. B.; Trejo, C.; García-Nava, R.; Reyes-Agüero, J. A.; Rivera, J. R. A. Biophysical and physiological characteristics of nopalitos (Opuntia spp., Cactaceae) as influenced by domestication. Genetic Resources and Crop Evolution, v.62, p.927-938, 2015. https://doi.org/10.1007/s10722-014-0201-7

Ginkel, M. van; Sayer, J.; Aw-Hassan, A.; Bossio, D.; Craufurd, P.; El Mourid, M.; Haddad, N.; Hoisington, D.; Johnson, N.; Velarde, C. L.; Mares, V.; Mude, A.; Nefzaoui, A.; Noble, A.; Rao, K. P. C.; Serraj, R.; Tarawali, S.; Vodouhe, R.; Ortiz, R. An integrated agro-ecosystem and livelihood systems approach for the poor and vulnerable in dry areas. Food Security, v.5, p.751-767, 2013. https://doi.org/10.1007/s12571-013-0305-5

Hassan, S.; Inglese, P.; Gristina, L.; Liguori, G.; Novara, A.; Louhaichi, M.; Sortino, G. Root growth and soil carbon turnover in Opuntia ficus-indica as affected by soil volume availability. European Journal of Agronomy, v.105, p.104-110, 2019. https://doi. org/10.1016/J.EJA.2019.02.012

Lima, L. R.; Silva, T. G. F. da; Jardim, A. M. da R. F.; Souza, C. A. A. de; Queiroz, M. G. de; Tabosa, J. N. Growth, water use and efficiency of forage cactus sorghum intercropping under different water depths. Revista Brasileira de Engenharia Agrícola e Ambiental, v.22, p.113-118, 2018. https://doi.org/10.1590/1807-1929/agriambi.v22n2p113-118

Morais, J. E. F. de; Silva, T. G. F. da; Queiroz, M. G. de; Araújo, G. G. L. de; Moura, M. S. B.; Araújo Junior, G. do N. Hydrodynamic changes of the soil-cactus interface, effective actual evapotranspiration and its water efficiency under irrigation. Revista Brasileira de Engenharia Agrícola e Ambiental, v.21, p.273-278, 2017. https:// doi.org/10.1590/1807-1929/agriambi.v21n4p273-278

Mottese, A. F.; Naccari, C.; Vadalà, R.; Bua, G. D.; Bartolomeo, G.; Rando, R.; Cicero, N.; Dugo, G. Traceability of Opuntia ficus-indica L. Miller by ICP-MS multi-element profile and chemometric approach. Journal of the Science of Food and Agriculture, v.98, p.198-204, 2018. https://doi.org/10.1002/jsfa.8456

Neder, D. G.; Costa, F. R. da; Edvan, R. L.; Souto Filho, L. T. Correlations and path analysis of morphological and yield traits of cactus pear accessions. Crop Breeding and Applied Biotechnology, v.13, p.203-207, 2013. https://doi.org/10.1590/ S1984-70332013000300009

Nobel, P. S.; Zutta, B. R. Temperature tolerances for stems and roots of two cultivated cacti, Nopalea cochenillifera and Opuntia robusta: Acclimation, light, and drought. Journal of Arid Environments, v.72, p.633-642, 2008. https://doi.org/10.1016/j. jaridenv.2007.08.005

Pereira, P. de C.; Silva, T. G. F. da; Zolnier, S.; Morais, J. E. F. de; Santos, D. C. dos. Morfogênese da palma forrageira irrigada por gotejamento. Revista Caatinga, v.28, p.184-195, 2015. https://doi. org/10.1590/1983-21252015v28n321rc
Pinheiro, K. M.; Silva, T. G. F. da; Diniz, W. J. da S.; Carvalho, H. F. de S.; Moura, M. S. B. de. Indirect methods for determining the area index of forage cactus cladodes. Pesquisa Agropecuária Tropical, v.45, p.163-171, 2015. https://doi.org/10.1590/1983-40632015v4530617

Queiroz, M. G. de; Silva, T. G. F. da; Zolnier, S.; Silva, S. M. S. e; Souza, C. A. A. de; Carvalho, H. F. de S. Relações hídrico-econômicas da palma forrageira cultivada em ambiente Semiárido. Irriga, v.1, p.141-154, 2016. https://doi.org/10.15809/irriga.2016v1n01p141-154

R Core Team. R: A language and environment for statistical computing. R Foundation for Statistical Computing, Vienna, Austria, 2020. Available at: <https://www.r-project.org/>. Access in: Jul. 2020.

Reis, C. M. G.; Gazarini, L. C.; Fonseca, T. F.; Ribeiro, M. M. Aboveground biomass estimation of Opuntia ficus-indica (L.) Mill. for forage crop in a Mediterranean environment by using nondestructive methods. Experimental Agriculture, v.54, p.227-242, 2018. https://doi.org/10.1017/S0014479716000211

Richards, L. A. Diagnosis and improvement of saline and alkali soils. Washington: United States Department of Agriculture, 1954. 159p. Agricultural Hand Book, 60

Rocha, S. S.; Londe, L. C. N.; Pimenta, S.; Cardoso, M. M.; Gonçalves, N. P.; Gomes, W. S.; Calaes, J. G. Congruence between morphological and molecular markers for genetic diversity analysis applied to forage palm genotypes propagated via bioreactors. Industrial Crops and Products, v.147, p.1-7, 2020. https://doi.org/10.1016/j. indcrop.2020.112230

Silva, T. G. F. da; Araújo Primo, J. T.; Moura, M. S. B. de; Silva, S. M. S. e; Morais, J. E. F. de; Pereira, P. de C.; Souza, C. A. A. de. Soil water dynamics and evapotranspiration of forage cactus clones under rainfed conditions. Pesquisa Agropecuária Brasileira, v.50, p.515525, 2015. https://doi.org/10.1590/S0100-204X2015000700001

Silva, T. G. F. da; Araújo Primo, J. T.; Silva, S. M.S e; Moura, M. S. B. de; Santos, D. C. dos; Silva, M. da C.; Araújo, J. E. M. Indicadores de eficiência do uso da água e de nutrientes de clones de palma forrageira em condições de sequeiro no Semiárido brasileiro. Bragantia, v.73, p.184-191, 2014b. https://doi.org/10.1590/ brag.2014.017

Silva, T. G. F. da; Miranda, K. R. de; Santos, D. C. dos; Queiroz, M. G. de; Silva, M. C. da; Cruz Neto, J. F. da; Araújo, J. E. M. Área do cladódio de clones de palma forrageira: Modelagem, análise e aplicabilidade. Revista Brasileira de Ciências Agrárias, v.9, p.633641, 2014a. https://doi.org/10.5039/agraria.v9i4a4553

Steidle Neto, A. J.; Lopes, D. C.; Toledo, J. V.; Zolnier, S.; Silva, T. G. F. da. Classification of sugarcane varieties using visible/near infrared spectral reflectance of stalks and multivariate methods. Journal of Agricultural Science, v.156, p.1-10, 2018. https://doi.org/10.1017/ S0021859618000539 